\title{
System and Neural Network Analysis of Economic and Financial Development - A case study of Dubai and rest of UAE
}

\author{
Genanew B.Workua, Ananth Rao ${ }^{b, *}$ \\ aDubai Business School, University of Dubai, Dubai, United Arab Emirates, gbekele@ud.ac.ae \\ ${ }^{b}$ Dubai Business School, University of Dubai, Dubai, United Arab Emirates, arao@ud.ac.ae \\ ${ }^{*}$ Corresponding author.
}

Received: 25 November 2017, revised: 20 February 2018, accepted: 5 April 2018, published: 15 April 2018

\begin{abstract}
The study examines the factors affecting the economic and financial development by applying Zellner's seemingly unrelated regressions (SURE) and Neural Network techniques. It applies multivariate and neural network frameworks for analysing the GDP of Dubai and rest of UAE using data for 2001-2015. The study shows that there exists positive interdependencies between Dubai and rest of UAE economies. This signifies that the core competencies across various sectors in Dubai and rest of UAE economies need to be promoted further to have overall diversified impact on UAE economy. The positive sizable impact of the finance sector in Dubai and negative sizable impact in the rest of the UAE provide many opportunities for designing diversification programs for sustained economic development of the entire UAE economy. The small sample size, nonavailability of detailed sectoral data in four of the seven emirates constrained the scope of the study for generalization to other economies in the Middle East. The study findings are crucial for identifying structural reforms, to strengthen competitiveness and accelerate private sector-led job creation for nationals, potential on further opening up foreign direct investment (FDI), improving selected areas of the business environment, and easing access to finance for start-ups and SMEs in both the economies.
\end{abstract}

Keywords: SURE System analysis; Neural Network analysis; Dubai; UAE; GDP; Economic \& financial Development, FDI

JEL codes: C32, C52, D85, N15, N25

\section{INTRODUCTION}

The high-income diversified economic transformation of Dubai ${ }^{1}$ in particular and United Arab Emirates (UAE) in general have been significant over the last two decades. Concerted efforts have been made to make these economies less dependent on oil by diversifying to various sectors. In fact, the pace of reduction on oildependency has been fastest in UAE as compared to other GCC countries ${ }^{2}$. The diversification of the UAE economy is driven by the rapid expansion of services such as tourism, finance, transport and communication sectors. (IMF 2015). Hussain et al, (2008) report that the macroeconomic performance in ten oil-exporting countries including UAE is closely linked to world oil prices.

Fernandes and Karnik (2009) modelled the oil sector to examine its influence on the UAE economy, notably the government sector. The study concluded that, the UAE is indeed quite dependent on oil sector, despite the attempts to diversify. The study used optimal control technique and concluded that dependence on oil cannot continue indefinitely. This paper extends the work initiated in Fernandes and Karnik (2009) to predict the GDP and interdependencies among the oil and non-oil sectors for sustained growth, using new analytical tools such as multivariate and neural network models. Dubai is an interesting case for couple of reasons. Firstly, the emirate heavily relies on non-oil export based international trade. Secondly, the emirate is the relatively small local market size that renders the trade activities vital to the survival and growth of emirate's business plans.

\footnotetext{
${ }^{1}$ Dubai is one of the seven emirates in UAE. Other emirates are Abu Dhabi, Ajman, Sharjah, Umm-al-Quwain, Ras-EL Khaima, and Fujairah. Figure 3.1 shows the geography of UAE.

${ }^{2}$ GCC countries - Bahrain, Kuwait, Oman, Qatar, Saudi Arabia, and UAE. http://dx.doi.org/10.30585/irabml.v111.72
}

(c) 2018 the Authors. Production and hosting by Avicenna FZ LLC. on behalf of Dubai Business School, University of Dubai - United Arab Emirates. This is an open access article under the CC BY-NC license. 
The reasons to compare Dubai with the UAE economy is that, the UAE is a federal state of the seven economically interdependent emirates ${ }^{3}$. Another reason is that, IMF country report (2015) states that the large fiscal and external buffers built in this economy have spill over effects from the volatile oil prices,

sluggish global growth, and volatility in emerging market economies. Further, the UAE has always taken the lead in the region for being the most diversified economy, with its prudent investment in strategic drivers such as infrastructure, education, innovation, smart city development as detailed in its Vision (2025) document. Thus, the problem of predicating GDP for sustainability of economic diversification in Dubai compared to UAE as benchmark is of paramount importance to policy makers to ensure that the vision 2025 for Dubai is achievable. Specifically, this study examines the following research questions:

i. How are the various sectors interacting in Dubai and the rest of UAE's GDP?

ii. Is the interdependency predictable using advanced analytical tools such as multivariate system and neural network frameworks?

The paper is organized in to five sections. Section 2 reviews the literature and the conceptual framework proposed for the study. Section 3 discusses the methodology followed and data used in the study. It evaluates the interdependencies of the two economies using system model and neural network framework. Section 4 discusses the empirical estimates of the model. Section 5 concludes the study with policy implications, directions for future research and limitations.

\section{LITERATURE REVIEW \& CONCEPTUAL FRAMEWORK}

\subsection{Literature Review}

Sherif (2013) analyzed the unique unemployment anomaly in UAE and formulated a strategic policy to effectively combat the high rates of unemployment among UAE citizens. The policy is a federal plan of action for human resources development designed to reduce unemployment through stimulation of economic growth, increased productivity, educational system reforms, capital accumulation, skills development, and provision of skills consistent with labor market demands. Limitations of the research include the setting of priorities to ensure that implementation of each element of the strategy is cost effective. Findings reveal that complete implementation of the strategy is an effective solution to the unemployment problem in the country. The research offers a long-term practical solution to the problem of unemployment. Sherif's paper proposed short-term reforms to accelerate job creation and allow the government to formulate a development model and initiate longterm reforms which include improvement of labor impacts of macroeconomic policies, implementation of social VAT mechanism, reinforcement of migration policy, and reforms on public employment services.

Fiscal policy is the component by which oil price shocks are transmitted to non-oil economies. The correlation between oil prices and non-oil output has been higher in countries where oil dominates the economy. Husain et.al, (2008) shows that the fiscal policies' effect on oil price shocks enhances the business cycle in oil-exporting countries. Cevik's (2014) study shows that oil price fluctuations tend to influence the share of oil sectors and non-oil sectors in the GDP. Lower oil prices may lead to a higher share of non-hydrocarbon GDP, holding everything else constant.

Fernandes and Karnik (2009) observed that there is a substantial worsening of Gross Fiscal Deficit in UAE due to increases in the deficit every year, because of increase in expenditures and decline in the share of oil sector revenues. The second experiment in their study was with Gross Fiscal Deficit, in which the GDP was restricted to 3 percent of the nominal GDP. It was observed that the current balance showed a surplus yet it decreased by 27 percent due to the restriction of the GDP, requiring the government to pay close attention on its finances. The third experiment was conducted on the oil sector of the UAE in order to examine the after-effects of the decline in the production of crude oil, which adversely affected government finances and the economy. Unfortunately, the impact on the other non-oil sectors was not addressed in the above experiments. Guo and Kliesen (2005) showed that there is positive effect of the increase in oil price for GDPs of oil-exporting countries, and negative effects on GDPs for oil-importing countries.

\footnotetext{
${ }^{3}$ UAE Federal Government is responsible for foreign affairs, security and defence, nationality and immigration issues, as well as education, public health, currency, postal, telephone and other communication services such as air traffic control, licensing of aircraft, labour relations, financial services (including banking and insurance), delimitation of territorial waters, and extradition of criminals.
} 
The education sector is one of the growing sectors contributing to the diversification of the UAE. The education sector drives monetary development by enticing more UAE national students to take interest in activities related to manufacturing and industrial sectors and take them as career paths. Traditionally these sectors were reserved for expatriates. To thrive in the long-run, industry is making itself more attractive to UAE nationals (Dhaheri, 2016). Structural reforms are pursued to strengthen the competitiveness.

On the fiscal front, while Dubai's government debt sustainability has improved, it could rise rapidly under severe shocks: (i) a sharp decline in GDP growth in 2015 (by 3/4 of standard deviation from the baseline) and a gradual recovery in 2016-20 would raise the debt-to-GDP ratio by about 6 percentage points in 2020 compared to the baseline; (ii) under a severe global downturn scenario, which assumes a real GDP shock, lower real interest rates, and deterioration in the primary balance in the medium term, Dubai's government debt would increase to about 32 percent of GDP in 2020; (iii) a scenario that combines a global downturn with a real estate shock, under which the government would take over 20 percent of the GREs' total debt in the medium term, would imply a substantial increase in the government debt-to-GDP ratio, to about 54 percent, more than twice as large as under the baseline (IMF Country Report 2016).

\subsection{Conceptual Framework}

Figure 2.1 conceptualizes the economic growth as a cycle with complex chain of events, reinforced through a feedback to represent the long-term expansion of the productive potential of a country.

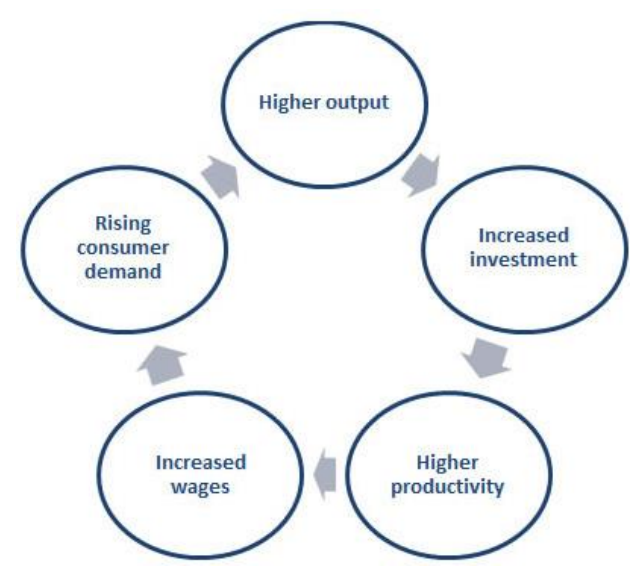

Figure 2.1: Conceptual Framework of the Study - Circle of Economic Growth

The vicious circle of economic growth emphasizes the key drivers of growth and the factors that determine the long-run increases of a nation's GDP, which includes higher output, increased investment, higher productivity, increased wages, and rising consumer demand. Each factor varies in importance for a nation at a given point in time. Increased consumer demand will lead to higher output that result in increased investment. The framework presents the advantages of economic growth in terms of higher standards of living, generation of more jobs that facilitates entry into the labor market, and fiscal dividend that will provide the government capability for improvement in public services and budget deficit reduction. The framework focuses on rising consumer demand and output that encourage investment to sustain economic growth through increased longrun aggregate supply. Economic growth is viewed as having positive impact on consumer and business confidence that promote consumer purchases. The cycle is expected to continue in the direction of the momentum until an external factor will intervene.

We apply this framework to UAE and Dubai economies for answering research questions for several reasons. Firstly, the UAE has a commodity-based economy with oil shipments and natural gas contributing to 40 percent of total exports, equivalent to 38 percent of GDP Annual Economic Report (2013). Secondly, it has one of the world's highest GDP per capita, providing huge investments in financial, construction, and tourism sectors as a strategy for economic diversification and reduction of dependence on oil revenues. In 2012, drivers of economic growth included tourism, which accounted for 15.5 percent of output growth, manufacturing activities, wholesale and retail trade, and transport and communication sectors. Economic stability was gradually achieved with the process of diversification and the recovery witnessed by the real estate and construction industry. 
Thirdly, the country is seen to enjoy a strong economy supported by effective economic and investment policies and ideal investment climate creating a strong positive impact on the flow of foreign investments. IMF 2016 study show that, GDP growth rate in UAE was 4.6 percent in 2014 and averaged 4.82 percent from 2000 to 2016 , reaching a high record of 9.80 percent in 2006 and a low record of -5.20 percent in 2009. Nominal GDP of UAE in 2016 was estimated at US\$ 382 billion compared to US $\$ 373$ billion in 2012, showing marginal growth between the two periods. The non-oil sectors grew by 3.4 percent representing 67.3 percent of UAE's GDP. GDP Growth Rate is projected to trend around 4.28 percent in 2020, 4.24 percent in 2030 and 4.24 percent in 2050. UAE managed to overcome the effects of global financial crisis, financial difficulties of European nations, and the rise in unemployment rate, through its balanced economic policies, and effective government leadership. Despite the global economic crisis, UAE economy enjoyed the benefits of economic diversification, increased spending in infrastructure projects, rise in oil prices, and tourism projects. UAE continues to attract more foreign investments through the creation of a favourable investment climate and laws that promote economic climate and business environment (IMF (2016)). In the 1960s and 70s, Dubai was an oil export hub. To facilitate the export, all revenues from oil were utilized to build the requisite infrastructure, namely, the Jebel Ali Port, Dubai International Airport, and Port Rashid, anticipating the long-term sustainability of the non-oil sector in Dubai and the UAE. In the 1980s, the economy was diversified further to become the Trade, Services and Industry hub. In this period, the principal projects were the Dubai Creek, Emirates Airline, Gold and Commodities Exchange, Dubai Dry Docks, and the Jebel Ali Free Zone. In the 1990s, the main projects were the development of the Academic City, Knowledge Village, Road projects and Healthcare City, all of which became the Education, Health, and Communication Hubs. The third Millennium years were all about Tourism and Urbanization. Dubai achieved a major milestone by building the world's tallest building, the Burj-Khalifa, and other tourist attractions like Palm Jumeirah, Burj-al-Arab, Dubai Metro, various shopping malls, and so on. In the 2010s, the government focused on the sustainability of the economy through innovation (Rettab, 2016).

Fourthly, the driving force for sustained economic performance in the non-oil sector is attributed to immense financial surpluses in infrastructure projects. Stability remains the hallmark of the nation economic activity with a continuing focus on infrastructure projects expenditures. It is expected that stability of the various industries, improvements in the real estate industry, tourism, and rising growth in economic performance will contribute to the nation attractiveness for investments. The generated growth rates of UAE demonstrate the success of the diversification policy on income sources and reduction of oil reliance in the light of global financial crisis. The high level of oil prices in earlier periods boosted government revenues and provided resources for public spending and stimulation of investment. With the foregoing rationale for the conceptual framework, we formulate the following operational hypotheses:

\subsection{Operational Hypotheses}

A study by Awokuse (2007) indicate that import and export stimulates financial development. Shahbaz, Khan, and Tahir (2013) have shown a positive relationship between exports, imports and economic growth, whereas Uğur (2008) show that imports have a unidirectional relationship between GDP and consumption of import goods. With these mixed results, since Dubai (in particular) and the UAE (in general) are predominantly reexport markets, we hypothesize, $\mathrm{H} 1$ : There is positive relationship between re-exports and GDPs in Dubai and other Emirates in the UAE.

Calderón and Liu (2003) observed Granger Causality from financial development to economic growth and vice versa co-exist. Their study showed that financial development leads to economic growth. Hassan and Yu (2007) investigated a positive relationship between financial development and economic growth. The short-term multivariate analysis in their study resulted in mixed results: first, there is a two-way causality between growth and finance for most regions, and, second, in the poorest regions there is a two-way causality. Thus, we hypothesize, H2: The relationship between the financial sector and the GDPs of Dubai and other Emirates in the UAE are positive.

Mahonye and Mandishara (2015) show that the mining sector is export-oriented giving different nation's development stimulus. The researchers argue that there is a negative relation between GDP and the mining sector. On the other hand, Shakouri and Yazdi's (2012) study on Iran show that the economic growth of Iran is linked to the export of mineral resources. To attain economic growth, emphasis on exports in the mining sector is necessary. Thus, we hypothesize, H3: The relationship between the mining sector and GDPs of other Emirates in the UAE and Dubai is positive.

Chui and Chau (2005) state that there is no relationship between real estate and economic growth. The study examines the lead-lag relationship between the variables in Hong Kong. The absence of relationship is because 
of the critical variety in the project's duration in Hong Kong. On the other hand, Hong (2014) estimates a positive relationship between real estate investment and economic growth through panel analysis of 284 Chinese cities. Turin (1969) argued that there is positive relationship between the construction sector and economic growth. Drewer (1997) argued that global construction output has turned out to be progressively concentrated in the developed market economies. In light of these mixed arguments and to clarify the situation in the present research, we hypothesize, $\mathrm{H} 4$ : The relationship between the GDPs of Dubai and other Emirates in the UAE with the construction and the real estate sector is positive.

Ajmair (2014) examined the components of manufacturing and industry sector through simple linear regression and concluded that there was positive relationship between manufacturing sector and GDP. We hypothesize, H5: The relationship between the GDPs of Dubai and other Emirates in the UAE and manufacturing sector is positive

Gao, et.al (2016) show a positive relationship between GDP and development in freight transport. Aqeel and Sabihuddin Butt, (2001) show that energy consumption leads to economic growth as it directly causes employment. A study by Wang (2009) prove the bilateral relationship between transport and economic growth. The result states that proper transportation system can realize economic development. In view of these mixed results, we hypothesize, H6: The relationship between the GDPs of Dubai and the other Emirates in the UAE with transport, communication and storage sector is positive.

\section{METHODS}

We apply two techniques in our study: the first is the econometric technique using SURE (explained below) to test the hypotheses, and the second by using Neural Network (NN) to analyze the growth and sustainability of GDP in Dubai and rest of UAE as NN is devoid of distributional assumptions that are normally seen in econometric techniques.

\subsection{System Analysis using SURE}

Despite being independent entities though, the seven emirates of the UAE (Abu Dhabi, Dubai, Sharjah, Ajman, Umm Al Quwain, Ras Al Khaima and Fujairah) are economically interdependent. This study, therefore, models these interactions in a system context. Consequently, Zellner's seemingly unrelated regressions (SURE) technique is used to examine the relative contribution of sectors to Dubai, as an individual Emirate, and to the rest of UAE economy. The set of estimable systems of equations are:

$$
\left.\begin{array}{c}
U A E G D P\left(G D P_{U}\right)=f\left[\text { Constant }+\sum_{i}^{k} \beta_{i u} X_{i u}+\varepsilon_{i u}\right] \\
\text { Emirate }_{J} G D P\left(G D P_{j}\right)=f\left[\text { Constant }+\sum_{i}^{m} \beta_{i j} X_{i j}+\varepsilon_{i j}\right]
\end{array}\right\}
$$

Where

$X_{\text {iu }} \mathrm{i}=1,2, \ldots, \mathrm{k}$ represents the sectoral attributes to the GDP of Dubai \& rest of the UAE;

$X_{i j} \mathrm{i}=1,2, \ldots, \mathrm{n}$ represents the sectoral attributes to the GDP of Emirate $\mathrm{j}$;

$\beta_{i u}$ and $\beta_{i j}$ are respective system coefficients on the sectoral attributes to the GDP of the UAE and Emirate j.

Because of the interdependency and spill over effects among the economies of the seven Emirates, the error terms $\varepsilon_{i u}$ and $\varepsilon_{i j}$ in the above systems of equations (equation 3.1) are not independent. Estimating the parameters $\beta_{i u}$ and $\beta_{i j}$ by OLS per equation is consistent, but is inefficient if the disturbances for the different individual equations display contemporaneous correlation and the regressors sets differ across equations since emirate-wise economic diversification and specialization a particular Emirate, the explanatory variables $\left(X_{i u}\right.$ and $X_{i j}$ ) may not be the same for the system equations. Consequently, unconstrained generalized least squares (GLS) estimator will be used for empirical analysis of this study. GLS estimates obtained through iteration procedures are maximum likelihood estimates. In view of these inter-dependencies we hypothesize, $\boldsymbol{H}_{7}$ : There exists contemporaneous correlation across error terms $\left(\varepsilon_{i u}\right.$ and $\left.\varepsilon_{i j}\right)$ between the two sets of economies, i.e. covariance $\sigma_{u j} \neq 0$. 


\subsection{Neural Networki Architecture}

Like the linear and polynomial approximation methods in econometrics, a neural network relates a set of input variables $\left\{x_{i}\right\}, i=1, \ldots, k$, to a set of one or more output variables, $\left\{y_{j}\right\}, j=1, \ldots, k$. The difference between a $\mathrm{NN}$ and the other approximation methods is that the neural network makes use of one or more hidden layers, in which the input variables are squashed or transformed by a special function, known as a logistic or log sigmoid transformation. While this hidden layer approach may seem esoteric, it represents a very efficient way to model nonlinear statistical processes. Feedforward Network in Figure 3.1 illustrate the architecture on a NN with one hidden layer containing two neurons, three input variables $\left\{X_{i}\right\}, i=1,2,3$, and one output $y$.

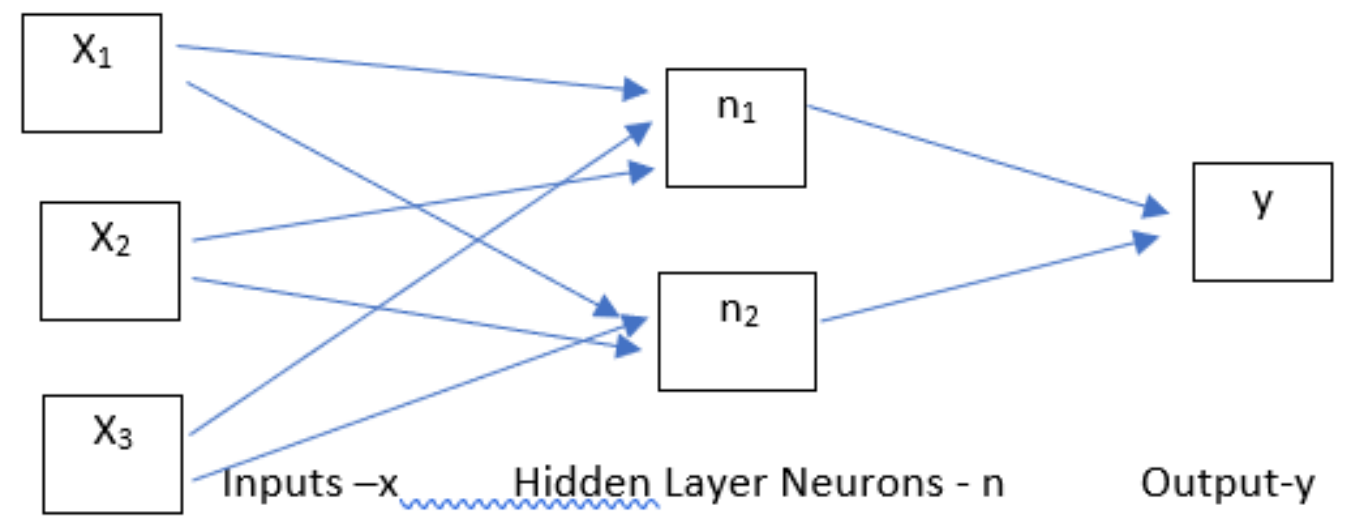

\section{Figure 3.1 Feedforward neural network}

We see parallel processing in this network. In addition to the sequential processing of typical linear systems, in which only observed inputs are used to predict an observed output by weighting the input neurons, the two neurons in the hidden layer process the inputs in a parallel fashion to improve the predictions. The connectors between the input variables, often called input neurons, and the neurons in the hidden layer, as well as the connectors between the hidden-layer neurons and the output variable, or output neuron, are called synapses ${ }^{4}$. This single-layer feedforward or multi-perceptron network with one hidden layer is the most basic and commonly used neural network in behavioural economic and financial applications. More generally, the network represents the way the human brain processes input sensory data, received as input neurons, into recognition as an output neuron. As the brain develops, more and more neurons are interconnected by more synapses, and the signals of the different neurons, working in parallel fashion, in more and more hidden layers, are combined by the synapses to produce more nuanced insight and reaction ${ }^{5}$. In behavioural finance \& economic applications, the combining of the input variables into various neurons in the hidden layer has another interpretation. Quite often we refer to latent variables, such as expectations, as important driving forces in markets and the economy as a whole ${ }^{6}$. While it is often possible to obtain survey data of expectations at regular frequencies, such survey data come with a time delay. There is also the problem that how respondents reply in surveys may not always reflect their true expectations. The use of the NN to model the process of decision making is based on the principle of functional segregation, which Rustichini et al. (2002) define as "not all functions of the brain are performed by the brain as a whole". A second principle, called the principle of functional integration, states that "different networks of regions (of the brain) are activated for different functions, with overlaps over the regions used in

\footnotetext{
${ }^{4}$ Most problems we work with, fortunately, do not involve a large number of neurons engaging in parallel processing, thus the parallel processing advantage, which applies to the way the brain works with its massive number of neurons, is not a major issue.

${ }^{5}$ Of course, very simple input sensory data, such as the experience of heat or cold, need not lead to processing by very many neurons in multiple hidden layers to produce the recognition or insight that it is time to turn up the heat or turn on the air conditioner. As experiences of input sensory data become more complex or diverse, more hidden neurons are activated, and insight as well as decision is a result of proper weighting or combining signals from many neurons, perhaps in many hidden layers. A commonly used application of this type of network is in pattern recognition in neural linguistics, in which handwritten letters of the alphabet are decoded or interpreted by networks for machine translation.

${ }^{6}$ Keynes referred quite often to "animal spirits" of investors in times of boom and bust, and we often refer to bullish (optimistic) or bearish (pessimistic) markets.
} 
different networks" [Rustichini et al. (2002), p. 3]. Making use of experimental data and brain imaging, they offer evidence that subjects make decisions based on approximations, particularly when subjects act with a short response time. They argue for the existence of a "specialization for processing approximate numerical quantities" [Rustichini et al. (2002), p. 16].

In a more general econometric framework, NN approximation is a sieve estimator. In the univariate case, with one input $\mathrm{x}$, an approximating function of order $\mathrm{m}, \Psi \mathrm{m}$, is based on a non-nested sequence of approximating spaces:

$$
\Psi_{m}=[\psi m, 0(x), \psi m, 1(x), \ldots \psi m, m(x)]
$$

Each finite expansion $\{\psi \mathrm{m}, 0(\mathrm{x}), \psi \mathrm{m}, 1(\mathrm{x}), \ldots \psi \mathrm{m}, \mathrm{m}(\mathrm{x})\}$, can potentially be based on a different set of Jump Connections. One alternative to the pure feedforward network or sieve network is a feedforward network with jump connections, in which the inputs $x$ has direct linear links to output $y$, as well as to the output through the hidden layer of squashed functions as in Figure 3.2, which is analogous to adaptive learning.

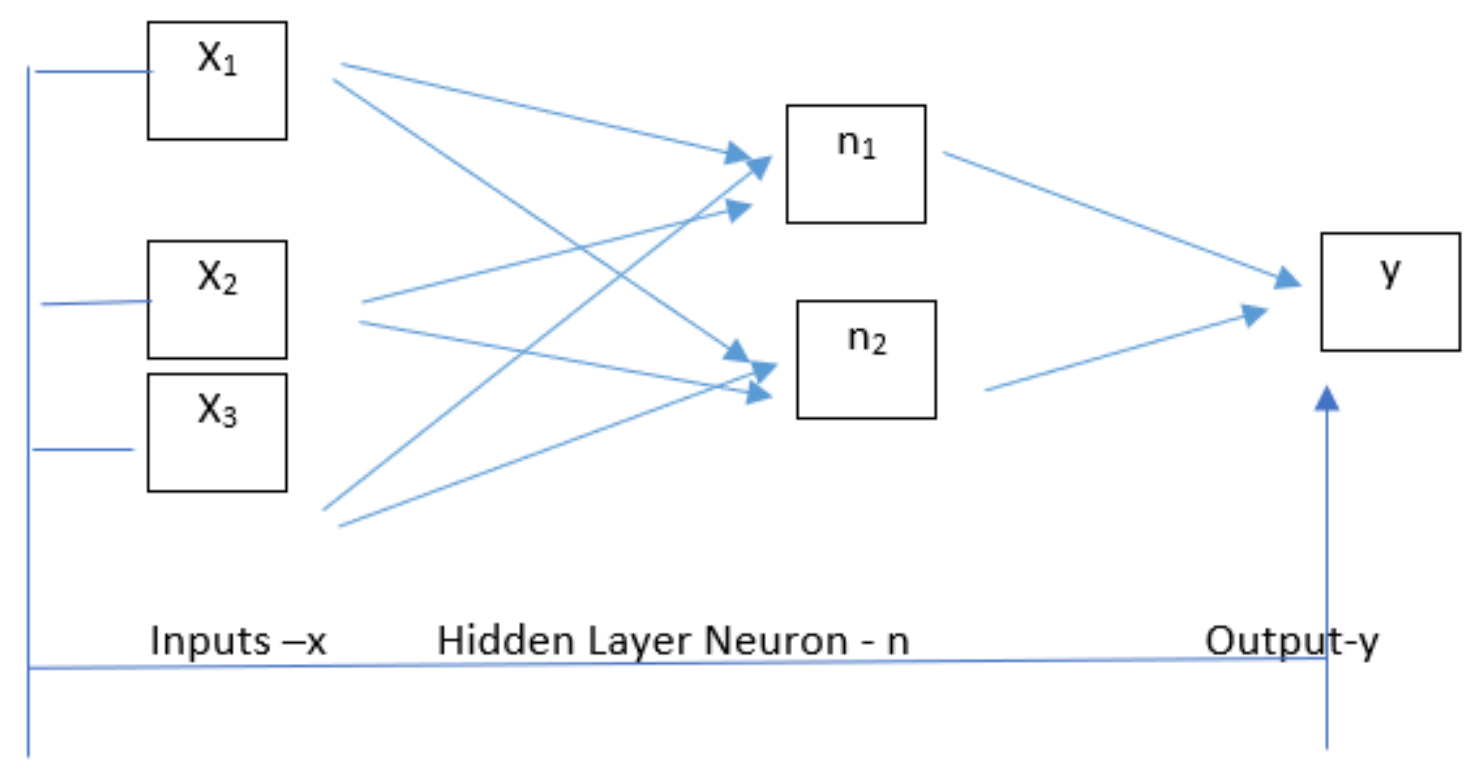

Figure 3.2 Feedforward neural network with jump connections

\subsection{The Empirical Model}

We state SURE framework through the following empirical model:

$$
\left.\begin{array}{c}
G D P_{U A E \text { Except } D x b_{t}}=f\left(\operatorname{REX}_{U_{t}}, \operatorname{MIN}_{U_{t}}, W R T_{U_{t}}, C R E S T_{U_{t}}, M_{A N}, T S C_{U_{t}}, F I N_{U_{t}}\right)+\epsilon_{U_{t}} \\
G D P_{\text {Dubai }_{t}}=f\left(\left(\operatorname{REXP}_{D_{t}}, M I N_{D_{t}}, W R T_{D_{t}}, C R E S T_{D_{t}}, M A N_{D_{t}}, T S C_{D_{t}}, F I N_{D_{t}}\right)+\epsilon_{D_{t}}\right.
\end{array}\right\}
$$

Where subscript $U_{t}$ denotes all emirates in UAE except Dubai in year t, while subscript $\mathrm{D}$ denotes Dubai year $\mathrm{t}$, $\epsilon_{U}$ and $\varepsilon_{D}$ are the error terms, and independent variables are as described in table 3.1. 


\subsection{Data}

Time series data for economic sectors of Dubai is obtained from the Statistical Yearbooks published by the Dubai Statistics Centre for various years. Sectoral level data for UAE and Dubai is obtained from the UAE Federal Competitiveness and Statistics Authority (FCSA), and these data is used to generate the data for all emirates in UAE except Dubai. Both UAE and Dubai level GDP and sectoral data are collected for the period 2001-2015. The dependent variable used in this study is real gross domestic product (GDP). The definition and expected effect (on real GDP) of the independent variables used ${ }^{7}$ are presented in table 3.1.

Table 3.1: Variable description (Units are in Billion AED)

\begin{tabular}{|c|c|c|c|}
\hline Variable (Code) & Definition & $\mathrm{H}_{\mathrm{i}}$ & $\begin{array}{l}\text { Expected } \\
\text { Coefficient } \\
\text { Sign }\end{array}$ \\
\hline $\begin{array}{l}\text { Re-export sector } \\
\text { (REXP) }\end{array}$ & $\begin{array}{l}\text { Re-exports are functions of international trade, and involve importing goods } \\
\text { and services for export it as value added goods and services }\end{array}$ & $\mathrm{H}_{1}$ & + \\
\hline $\begin{array}{l}\text { Financial } \\
\text { Sector(FIN) }\end{array}$ & $\begin{array}{l}\text { The financial sector is a classification of stocks containing firms that give money- } \\
\text { related services to business and retail clients; this segment incorporates banks, } \\
\text { investment funds, insurance agencies and real estate. }\end{array}$ & $\mathrm{H}_{2}$ & + \\
\hline $\begin{array}{l}\text { Mining sector } \\
(\mathrm{MIN})\end{array}$ & $\begin{array}{l}\text { The mining sector is the act, process or business of extraction of ore or mineral } \\
\text { from the ground. }\end{array}$ & $\mathrm{H}_{3}$ & + \\
\hline $\begin{array}{l}\text { Construction and } \\
\text { Real Estate } \\
\text { sector (CREST) }\end{array}$ & $\begin{array}{l}\text { The construction industry comprises three sectors, namely; infrastructure, } \\
\text { building and industrial. Building is further divided into residential and non- } \\
\text { residential. Real estate is business relating to land or any immovable property } \\
\text { like buildings, fixtures etc. }\end{array}$ & $\mathrm{H}_{4}$ & + \\
\hline $\begin{array}{l}\text { Manufacturing } \\
\text { sector (MAN) }\end{array}$ & $\begin{array}{l}\text { The manufacturing sector comprises industries engaged in chemical, } \\
\text { mechanical, or physical transformation of materials, substances, or components } \\
\text { into consumer or industrial goods. }\end{array}$ & $\mathrm{H}_{5}$ & + \\
\hline $\begin{array}{l}\text { Transport, } \\
\text { Storage and } \\
\text { Communication } \\
\text { sector (TSC) }\end{array}$ & $\begin{array}{l}\text { The branch of manufacture and trade based on freight, transportation, } \\
\text { communications, and utilities. Freight and transportation include railroads, } \\
\text { trucking, and public transportation, including transit systems, highways, roads, } \\
\text { and bridges. Communications include radio and television, but not newspapers } \\
\text { and magazines }\end{array}$ & $\mathrm{H}_{6}$ & + \\
\hline
\end{tabular}

\section{ANALYSIS AND RESULTS}

\subsection{Summary Statistics}

Table 4.1 reports summary statistics of rest of UAE economies. Rest of UAE registered positive annual compounded growth in Finance $(0.7 \%)$, RE-exports $(0.67 \%)$ Transport $(0.52 \%)$, Construction \& Real Estate $(0.4 \%)$, Mining $(0.13 \%)$ and Manufacturing $(0.1 \%)$ sectors while it registered a negative growth in wholesale sector $(-0.23 \%)$. RE-exports showed highly significant skewness and kurtosis implying non-normal behavior in this area.

Table 4.2 reports summary statistics of Dubai economy. Interestingly the Dubai economy shows a different pattern of growth in various sectors compared to rest of UAE. Mining sector registered an annual compounded growth rate of $4.83 \%$, followed by wholesale sector $(1.29 \%)$, Finance $(1.15 \%)$, Transport $(0.97 \%)$, Construction \& Real Estate $(0.93 \%)$, manufacturing $(0.83 \%)$ and finally re-exports $(.81 \%)$. Mining sector showed highly significant skewness and kurtosis implying non-normal behaviour in this area. In the overall, Dubai's economy has headed to fastest expansion with $0.96 \%$ annual compounded growth rate as compared to $0.17 \%$ in rest of UAE during the study period.

\section{Table 4.1 Summary Statistics of rest of UAE (2001-15) Natural Log of Variables}

\footnotetext{
${ }^{7}$ There are still unobserved sectors and factors that may affect real GDP. However, we have filtered and selected the most suitable independent variables for optimum results.
} 


\begin{tabular}{lccccccc}
\hline UAE excluding Dubai & Min & Max & Mean & SD & SKEW & KURT & $\begin{array}{c}\text { Annual } \\
\text { Compounded } \\
\text { growth rate \% }\end{array}$ \\
\hline Real GDP-Rest of UAE & 13.28 & 13.65 & 13.44 & 0.11 & 0.6 & 0.3 & 0.17 \\
Re-Export & 0 & 12.23 & 9.80 & 2.88 & $-3.2^{* * *}$ & $11.1^{* * *}$ & 0.67 \\
Mining & 12.49 & 12.81 & 12.65 & 0.09 & 0.1 & -0.9 & 0.13 \\
Wholesale & 10.29 & 11.35 & 10.82 & 0.35 & 0.3 & -1.1 & -0.23 \\
CREST & 10.98 & 11.71 & 11.33 & 0.23 & 0.3 & -0.8 & 0.40 \\
Manufacturing & 10.70 & 11.09 & 10.94 & 0.11 & -0.6 & 0.7 & 0.10 \\
Transport & 10.24 & 11.06 & 10.75 & 0.26 & -0.5 & -0.7 & 0.52 \\
Finance & 9.78 & 10.85 & 10.34 & 0.31 & -0.3 & -0.3 & 0.70 \\
\hline
\end{tabular}

Table 4.2 Summary Statistics of Dubai (2001-15) Natural Log of Variables

\begin{tabular}{lccccccc}
\hline & Min & Max & Mean & SD & SKEW & KURT & $\begin{array}{c}\text { Annual } \\
\text { Compounded } \\
\text { growth rate \% }\end{array}$ \\
UAE excluding Dubai & & & & & & & 0.96 \\
\hline Real GDP-Rest of UAE & 11.10 & 12.81 & 12.22 & 0.64 & -0.9 & -0.9 & 0.81 \\
Re-Export & 10.36 & 12.36 & 11.59 & 0.62 & -0.7 & -0.5 & 4.83 \\
& 4.30 & 8.93 & 12.65 & 1.55 & $-2.4^{* * *}$ & & \\
Mining & & & & & & $4.1^{* * *}$ & 1.29 \\
Wholesale & 9.51 & 11.53 & 10.82 & 0.75 & $-0.9^{*}$ & -0.8 & 0.93 \\
CREST & 8.75 & 10.60 & 11.33 & 0.55 & -0.6 & -0.1 & 0.83 \\
Manufacturing & 9.26 & 10.67 & 10.94 & 0.45 & -0.9 & -0.4 & 0.97 \\
Transport & 9.23 & 10.67 & 10.75 & 0.52 & -0.7 & -0.9 & 1.15 \\
Finance & 8.92 & 10.59 & 10.34 & 0.64 & -0.8 & -1.1 & \\
\hline
\end{tabular}

\subsection{SURE Estimation}

A test for multicollinearity among the independent variables was carried out and variables with variance inflation factor (VIF) > 10 variables were excluded from the empirical analysis. Stationarity of time series was ensured by taking the first difference of the series as indicated in Figure 4.1. Data were used in billion AED instead of natural log to provide clarity in interpreting SURE model coefficients.

Figure 4.1: Correlogram
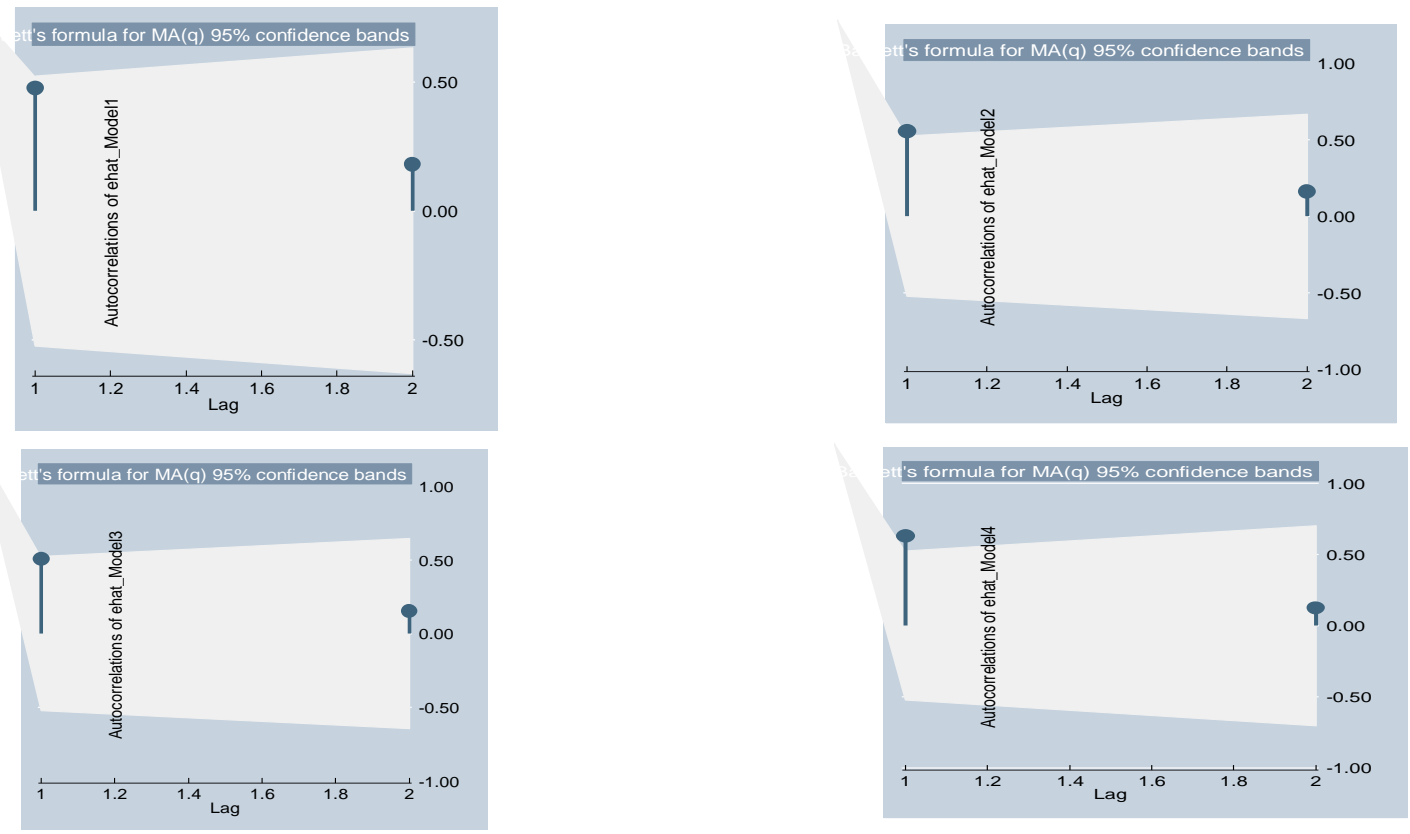
Four models were fitted to justify the robustness of the empirical analysis for both Dubai and rest of UAE (without Dubai). Regression estimation results are presented in table 4.3 for rest of UAE (without Dubai) and table 4.4 for Dubai.

For the rest of UAE data (see table 5.1), Model 1 includes the seven independent variables introduced earlier in this paper, and Model 2 includes these variables, except transportation, plus a dummy variable for the year 2008/2009. This dummy variable addresses the financial crisis period of Dubai and the UAE. Model 3 includes an additional variable for net export. This is intended to examine the effect of re-exports, as opposed to net exports. Given the economic structure of Dubai and the rest of UAE, re-exports and net export may measure economic concepts. In model 4, re-export is dropped while net export is maintained.

Table 4.3: Model Results for all emirates in UAE except Dubai (First Difference)

\begin{tabular}{lccccccccc}
\hline & & \multicolumn{2}{c}{ Model 1 } & \multicolumn{2}{c}{ Model 2 } & \multicolumn{2}{c}{ Model 3 } & \multicolumn{2}{c}{ Model 4 } \\
Real GDP & Code & Coef. & Std. Err. & Coef. & Std. Err. & Coef. & Std. Err. & Coef. & Std. Err. \\
\hline Year Dummy & & - & - & $-63449^{*}$ & 33092 & - & - & - & - \\
Re-Export & X1 & $0.712^{\star *}$ & .295 & 0.076 & 0.226 & $0.857^{* *}$ & 0.305 & - & - \\
Mining & X2 & $2.058^{* *}$ & .787 & 0.792 & 0.662 & $2.014^{* *}$ & 0.799 & 1.070 & 0.928 \\
Wholesale & X3 & $1.806^{*}$ & 1.000 & 0.263 & 0.676 & $1.995^{*}$ & 1.03 & 0.867 & 1.200 \\
CREST & X4 & 0.785 & 1.635 & 0.860 & 1.555 & 0.939 & 1.643 & 2.434 & 1.995 \\
Manufacturing & X5 & $-5.195^{*}$ & 2.787 & 2.530 & 3.408 & -4.792 & 2.838 & -3.073 & 3.725 \\
Transport & X6 & $7.846^{* *}$ & 3.246 & - & - & $8.158^{\star *}$ & 3.193 & 1.512 & 3.212 \\
Finance & X7 & $-6.802^{*}$ & 3.549 & 3.440 & 2.843 & $-7.476^{*}$ & 3.468 & 0.159 & 3.462 \\
Net Exports & X10 & - & - & - & - & -0.052 & 0.041 & 0.009 & 0.053 \\
Constant & & 32513 & 217306 & 116639 & 197126 & 2716.72 & 222839 & 201155 & 265876 \\
\hline
\end{tabular}

Table 4.4: Model Results for Dubai (First Difference)

\begin{tabular}{|c|c|c|c|c|c|c|c|c|c|}
\hline \multirow{2}{*}{$\begin{array}{r}\text { Dubai } \\
\text { Real GDP }\end{array}$} & \multirow[b]{2}{*}{ Code } & \multicolumn{2}{|c|}{ Model 1} & \multicolumn{2}{|c|}{ Model 2} & \multicolumn{2}{|c|}{ Model 3} & \multicolumn{2}{|c|}{ Model 4} \\
\hline & & Coef. & $\begin{array}{l}\text { Std. } \\
\text { Err. }\end{array}$ & Coef. & Std. Err. & Coef. & $\begin{array}{l}\text { Std. } \\
\text { Err. }\end{array}$ & Coef. & $\begin{array}{l}\text { Std. } \\
\text { Err. }\end{array}$ \\
\hline Dummy year & & - & - & 8849.4 & 5592.9 & - & - & - & - \\
\hline Re-Export & $\mathrm{X} 1 \mathrm{D}$ & -0.037 & 0.054 & -0.011 & 0.049 & -0.019 & 0.109 & - & - \\
\hline Mining & X2D & 0.082 & 0.936 & 0.424 & 0.861 & -0.226 & 1.035 & 0.053 & 0.980 \\
\hline Wholesale & X3D & $1.259^{\star \star}$ & 0.524 & $1.203^{\star \star}$ & 0.463 & $1.148^{*}$ & 0.566 & $1.225^{\star}$ & 0.556 \\
\hline CREST & X4D & $-1.734^{* *}$ & 0.589 & $-2.071^{\star \star \star}$ & 0.606 & $-1.920^{\star *}$ & 0.652 & $-1.817^{\star *}$ & 0.625 \\
\hline $\begin{array}{l}\text { Manufacturing } \\
\text { Transport }\end{array}$ & $\begin{array}{l}X 5 D \\
X 6 D\end{array}$ & $\begin{array}{l}3.091^{* *} \\
-1.163\end{array}$ & $\begin{array}{l}1.416 \\
0.850\end{array}$ & $\begin{array}{c}2.962^{\star *} \\
-\end{array}$ & $\begin{array}{c}1.160 \\
-\end{array}$ & $\begin{array}{l}3.714^{* *} \\
-1.447\end{array}$ & $\begin{array}{l}1.573 \\
0.928\end{array}$ & $\begin{array}{l}3.118^{*} \\
-0.944\end{array}$ & $\begin{array}{l}1.602 \\
0.916\end{array}$ \\
\hline $\begin{array}{l}\text { Finance } \\
\text { Net Exports } \\
\text { Constant }\end{array}$ & $\begin{array}{r}X 7 D \\
X 10 D\end{array}$ & $\begin{array}{c}5.572^{* \star *} \\
- \\
-3131.18\end{array}$ & $\begin{array}{c}1.202 \\
- \\
9615\end{array}$ & $\begin{array}{c}4.773^{\star \star *} \\
- \\
-6730.37\end{array}$ & $\begin{array}{c}0.880 \\
- \\
8949.43\end{array}$ & $\begin{array}{c}5.915^{\star * *} \\
-0.016 \\
-5273.84\end{array}$ & $\begin{array}{l}1.410 \\
0.067 \\
10372\end{array}$ & $\begin{array}{c}5.517^{* \star *} \\
-0.016 \\
-3770.72\end{array}$ & $\begin{array}{l}1.365 \\
0.035 \\
9971\end{array}$ \\
\hline \multicolumn{10}{|c|}{ SURE MODEL Diagnostics } \\
\hline R-squared & & \multicolumn{2}{|c|}{0.998} & \multicolumn{2}{|c|}{0.999} & \multicolumn{2}{|c|}{0.998} & \multicolumn{2}{|c|}{0.999} \\
\hline F-Value & & \multicolumn{2}{|c|}{$581.53^{\star * *}$} & \multicolumn{2}{|c|}{$697.97^{* * *}$} & \multicolumn{2}{|c|}{$426.41^{* * *}$} & \multicolumn{2}{|c|}{$575.58^{* * *}$} \\
\hline Log Likelihood & & \multicolumn{2}{|c|}{-291.67} & \multicolumn{2}{|c|}{-293.30} & \multicolumn{2}{|c|}{-282.67} & \multicolumn{2}{|c|}{-298.6} \\
\hline AIC & & \multicolumn{2}{|c|}{615.35} & \multicolumn{2}{|c|}{618.59} & \multicolumn{2}{|c|}{601.33} & \multicolumn{2}{|c|}{629.21} \\
\hline$\varepsilon_{12}$ & & \multicolumn{2}{|c|}{0.389} & \multicolumn{2}{|c|}{-0.264} & \multicolumn{2}{|c|}{0.534} & \multicolumn{2}{|c|}{0.069} \\
\hline $\mathrm{BP}\left(\mathrm{x}^{2}\right)$ & & \multicolumn{2}{|c|}{2.122} & \multicolumn{2}{|c|}{0.976} & \multicolumn{2}{|c|}{$4.047^{\star *}$} & \multicolumn{2}{|c|}{0.066} \\
\hline
\end{tabular}

Index: $\left({ }^{*}\right)$ significant at 10 percent, $\left({ }^{* *}\right)$ significant at 5 percent, $\left({ }^{* * *}\right)$ significant at 1 percent; BP: BreuschPagan test of independence of cross equations

The results from these alternative specifications suggests that Model 3 best fits the UAE data used in this study. This is evidenced from the comparison of the diagnostics (see the bottom panel of table 4.4), where Model 3 specification generates the lowest Akaike information criterion (AIC), highest R-square, highest Log likelihood 
and significant Brush Pagan test compared to the alternative specifications. Moreover, Model 3 seems intuitive given that its estimated coefficients are more reasonable in values and signs. For Dubai, a similar analysis suggests that Model 3 best fits the Dubai data, compared to the alternative specifications in table 4.4.

\subsubsection{SURE Empirical Results}

This section presents the empirical finding from Model 3 in Table 4.3 for rest of UAE and Table 4.4 for Dubai. As can be seen from the BP (Breusch-Pagan) test for independence of two equations, the contemporaneous correlation across cross equation error terms were not equal to zero. This validated hypothesis $7\left(\mathrm{H}_{7}\right)$ implying that the two economies (rest of UAE and Dubai) are positively affecting each other. This provides adequate justification for rest of UAE and Dubai economies to derive benefits from diversification of their sectors in which they have core competencies discussed below.

The coefficient of determination for the Model 3 (from model diagnostic in the bottom panel in Table 4.4) indicates that the model explains about 96 percent of the variation in both economies. The effect of sectors such as transport, mining, wholesale, and re-exports sectors were positive and significant (in decreasing order of magnitude of SUR coefficients) to the growth of rest of UAE GDP. A one percent increase in the share of transportation sector, increased rest of UAE GDP by 8.158 percent. The impact coefficient is big in magnitude. The reason could be due to the huge investment expenditure that UAE is investing from its coffers for completing its five-star infrastructure system both at the federal and individual emirate levels over the next several years. The investment projects include all modes of transportation infrastructure, including rail, shipping, and air and include project requirements associated with developments in other sectors. Road and Transport Authority projects alone include the USD 7 billion inter-Emirate Union Rail project, development of the new Port Khalifa, and expansion projects involving the international airport in Abu Dhabi. The results imply that such investments could be continued for positive spill over effect in the long-term in the rest of UAE.

A one percent increase in the share of Mining sector increased the rest of UAE GDP growth by 2.014 percent. Similarly, a one percent increase in wholesale sector increased the rest of UAE GDP growth by 1.995 percent. Similarly, a 1 percent increase in re-export sector showed a 0.857 percent increase in the growth of rest of UAE GDP. It is interesting to note that finance sector negatively affects rest of UAE GDP growth. The financial crisis period had no impact on UAE GDP.

For Dubai emirate, as expected Model 3 (table 4.4) results were very different from rest of Dubai GDP. The effect of sectors such as finance, manufacturing, and wholesale sectors were positive and significant (in decreasing order of magnitude of SUR coefficient) to the growth of Dubai GDP. A one percent increase in the share of finance sector increased the GDP growth of Dubai by 5.915 percent. As was detailed in earlier sections, Dubai's competitiveness lies in its finance sector. The Arab World Competitiveness Report 2007, issued by the World Economic Forum (WEF), ranks the UAE in the top position among Arab countries and in the $29^{\text {th }}$ position among the 40 most advanced economies. It states, "Sound economic management has contributed to stabilizing the macroeconomic environment and strengthening public institutions."

The manufacturing sector in Dubai has taken second spot in the model. A one percent increase in manufacturing sector increased Dubai GDP growth by 3.714 percent. Similarly, a one percent increase in wholesale sector increased Dubai GDP by 1.148 percent while the estimate was less significant at 10 percent.

This was expected since the Department of Economic Development (DED) has identified several major subsectors as the main drivers of the manufacturing economy including processed food and beverages, plastics, electrical machinery and equipment, chemicals, minerals, base metals and pearls and precious stones. The high degree of concentration in a few key sub-sectors highlights the potential for the growth of, and diversification within, the manufacturing sector. For instance, imports of electrical machinery and equipment along with pearls, precious stones and metals accounted for 70.8 percent of Dubai's manufactured goods imports. Similarly, exports and re-exports are dominated by electrical machinery and equipment along with pearls, precious stones and metals, accounted for 71 percent of Dubai's manufactured exports and re-exports. Despite the overall importance of manufacturing in Dubai's non-oil trade, the surprising degree of concentration of trade activity within a few key sub-sectors highlights the potential for diversification of Dubai's manufacturing trade.

The development of free economic zones has spurred investment in Dubai's manufacturing and wholesale sectors. These include the option of 100 percent foreign ownership of companies based there, exemption from corporate taxes for 50 years, on a renewable basis, and exemption too from personal income tax, import and re-export duties. Firms in the zone can also hire whom they like, as they are not bound by Emiratization policies, 
and there are no currency restrictions. The free zone also offers one-stop-shop services for setting up companies, visas and permits. Jebel-ALI free zone (JAFZA) is the flagship free zone operation of Economic Zones World (EZW). JAFZA is currently home to over 7,500 companies with 17 percent of these companies operating in IT and electronics, 15 percent in construction material, 12 percent in chemical and petroleum products, 12 percent in machinery and equipment, 10 percent in food and healthcare, 9 percent in automotive and 5 percent in the logistics sector. JAFZA generated trade worth more than US $\$ 90 \mathrm{bn}$ in 2014, providing more than 200,000 jobs in Dubai and the UAE. In addition, key to the industrial sector is the Dubai International Airport Free Zone (DAFZA), which contributed US\$30bn to Dubai's non-oil foreign trade in 2014. It offers the same incentives package as JAFZA and other zones, while also being located next to Dubai airport, a big logistical advantage for manufacturers there. While certain cargo services have moved to Al Maktoum International Airport at Dubai World Central (DWC), DAFZA is still very much a major hub for airborne imports and exports.

It is surprising to note that construction and real-estate sector in Dubai had a moderately significant negative impact on Dubai GDP. This is plausible, as rental growth declined, capital investments decreased, completion of pending projects resulted in oversupply and decreased demand and appetite for real estate by investors. Further, lenders continued to carefully scrutinize their real estate exposure, particularly for speculative development. Lender also required greater equity contributions (in addition to land) and other forms of security to support higher-risk lending. Mortgage caps were introduced to protect consumers and slow down sales price growth.

\subsubsection{Neural Network Results}

The procedure for using NN is first select data, create and train a network, and evaluate its performance using cross-entropy matrices. A two-layer feed-forward network, with hyperbolic-tangent hidden layer and softmax output neurons can categorise data vectors arbitrarily well, given enough neurons in its hidden layer. In our experiments, the number of hidden layer that gave best performance is 9 neurons (Figure 4.2). The neural network was trained with scaled conjugate gradient backpropagation. We have used the same data of 15 observations that were used with the SURE model and divided into two kinds of samples for the purpose of experimentations as in Table 4.5.

Table 4.5 Case Processing Summary

\begin{tabular}{llcc}
\hline & & $\mathrm{N}$ & Percent \\
\hline Sample & Training & 13 & $86.7 \%$ \\
& Testing & 2 & $13.3 \%$ \\
& Holdout & 0 & $0 \%$ \\
Valid & & 15 & $100.0 \%$ \\
Excluded & & 0 & \\
Total & & 15 & \\
\hline
\end{tabular}

As presented in table 4.5, $13(86.7 \%)$ data samples have been assigned for the training phase, and the network is adjusted according to its error. Also $13.3 \%$ data samples have been assigned for the testing phase. These have no effect on training and indicates an independent measure of network performance during and after training.

The training is done using backpropagation neural networks with 6 hidden neurons. It used Minimizing CrossEntropy (CE) results in good classification. Lower values are better. Zero means no error. Table 4.6 displays the error classification across two equations.

In training phase, the average overall relative error in equation $Y_{1}$ was $0.035 \%$, in equation $Y_{2}$ it was just $0.031 \%$. Similarly, in testing phase, the average overall relative error in equation $Y_{1}$ was $1.727 \%$, in equation $Y_{2}$ it was just $0.026 \%$. 


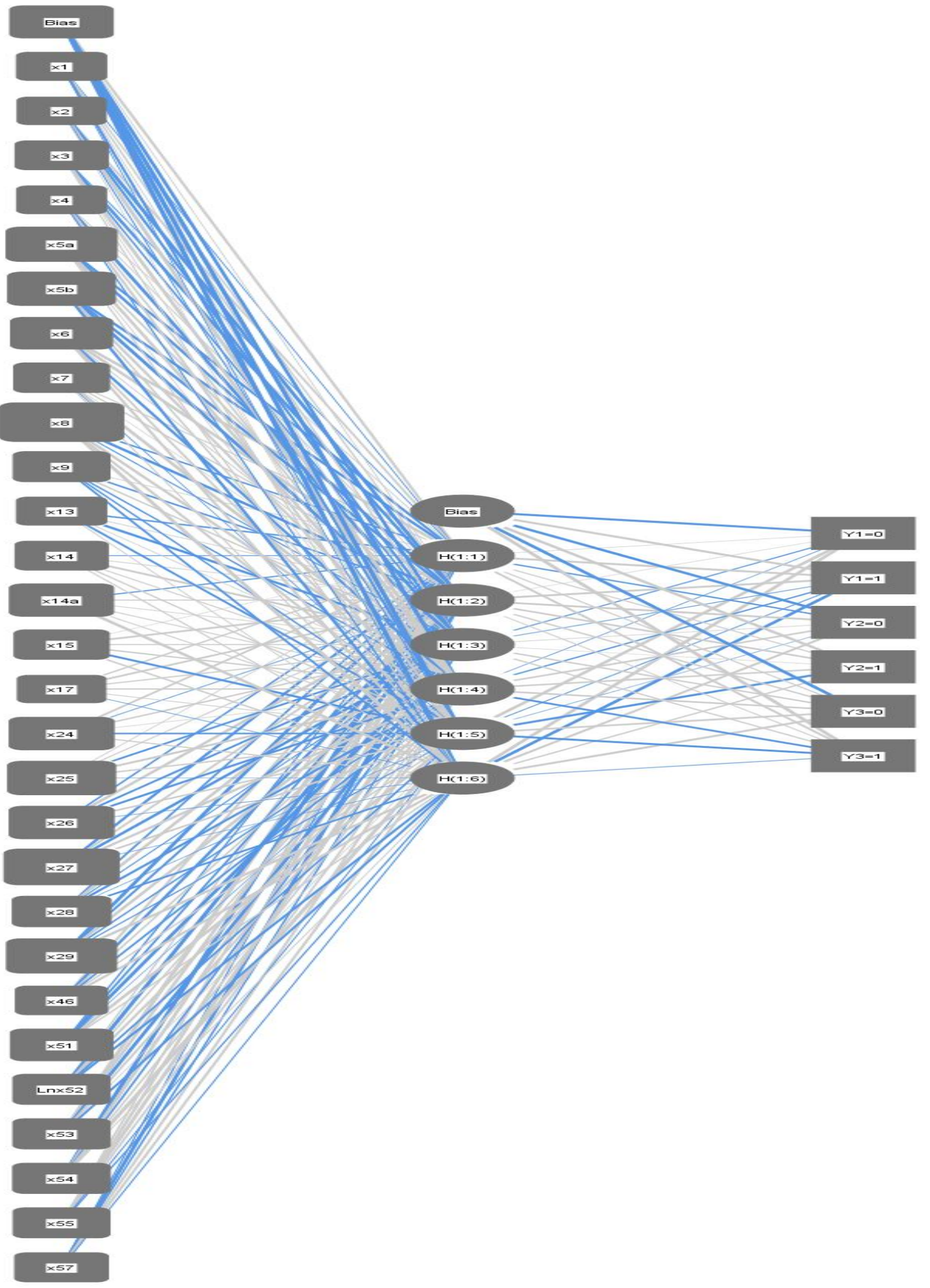

layer activation function: Hyperbalic tangent

Output layer activation function: Softmax

Figure 4.2 Feed Forward Neural Network with 15 inputs, 6 hidden neurons, and 2 outputs 
Table 4.6 NN Model summary of error classification across 2 equations

\begin{tabular}{|c|c|c|c|}
\hline \multirow{6}{*}{ Training } & \multicolumn{2}{|l|}{ Sum of Squares Error } & 0.332 \\
\hline & \multicolumn{2}{|c|}{ Average overall relative error } & 0.033 \\
\hline & \multirow{2}{*}{$\begin{array}{l}\text { Relative error for scale } \\
\text { Dependents }\end{array}$} & $\mathrm{Y} 1$ & 0.035 \\
\hline & & Y2 & 0.031 \\
\hline & \multicolumn{2}{|l|}{ Stopping Rule Used } & 1 consecutive step(s) with no decrease in error ${ }^{a}$ \\
\hline & \multicolumn{2}{|l|}{ Training Time } & $0: 00: 00.02$ \\
\hline \multirow{4}{*}{ Testing } & \multicolumn{2}{|c|}{ Sum of Squares Error } & $0.186^{\mathrm{a}}$ \\
\hline & \multicolumn{2}{|c|}{ Average overall relative error } & 0.175 \\
\hline & \multirow{2}{*}{$\begin{array}{l}\text { Relative error for scale } \\
\text { Dependents }\end{array}$} & $\overline{Y 1}$ & 1.727 \\
\hline & & $\bar{Y} 2$ & 0.026 \\
\hline
\end{tabular}

a. Error computations are based on the testing sample.

\section{DISCUSSION AND CONCLUSION}

\subsection{SURE Results Discussion}

Stability remains the hallmark of Dubai and rest of UAE economies with a continuing focus on infrastructure projects expenditures as growth in the various industries, improvements in the real estate industry, focus on ICT, tourism, and rising growth in economic performance will allow Dubai and rest of UAE to achieve sustainability in economic performance. Both economies are experiencing growth in economic performance and are expected to maintain stability in the coming years with the governments' efforts to achieve long-term development objectives as outlined in vision 2025 documents. This paper analysed the interrelationships between Dubai and UAE Economies and between various sectors within Dubai and UAE economy.

Cross equation positive correlation $\mathrm{c}=$ between Dubai and rest of UAE show that the core competencies across various sectors in Dubai and rest of UAE economies need to be promoted further to have overall diversified impact on UAE economy. As discussed in earlier sections, Dubai economy is more diversified towards non-oil sectors. Rest of UAE in general and Abu Dhabi emirate in particular is more oil-dependent while efforts are being made to diversify to manufacturing, mining and construction and real estate sectors. Table 5.1 summarizes the extent of validation of hypotheses formulated in section 3 .

- In Dubai, the finance sector is the first major sector and contributed significantly to the economy. This is mainly due to the sustained stimulus given to this sector since 1970s as Dubai is emerging as international financial centre as envisaged in Dubai Vision 2025. The second major significant sector is the manufacturing sector, which contributed significantly to the GDP of Dubai economy. The third sector is wholesale and retail which significantly and positively contributed to the growth of Dubai economy.

Table 5.1: Summary of hypotheses from the model results

\begin{tabular}{|c|c|c|c|}
\hline Variable & $\begin{array}{c}\text { Expected } \\
\text { Coefficient Sign }\end{array}$ & $\begin{array}{l}\text { Actual coefficient signs and } \\
\text { magnitude in rest of UAE } \\
\text { (excluding Dubai) economy } \\
\text { (from Table 4.3) }\end{array}$ & $\begin{array}{c}\text { Actual coefficient signs } \\
\text { and magnitude in Dubai } \\
\text { economy } \\
\text { (from Table 4.4) }\end{array}$ \\
\hline Re-export (REXP) sector & + & $+0.857^{* *}$ & -0.019 \\
\hline Mining (MIN) sector & + & $+2.014^{\star \star}$ & -0.226 \\
\hline Wholesale and Retail trade & + & $+1.995^{*}$ & $1.148^{*}$ \\
\hline $\begin{array}{l}\text { Construction and Real Estate } \\
\text { (CREST) sector }\end{array}$ & + & +0.939 & $-01.92^{* *}$ \\
\hline Manufacturing (MAN) sector & + & -4.792 & $+3.714^{* * *}$ \\
\hline $\begin{array}{l}\text { Transport, Storage and } \\
\text { Communication (TSC) sector }\end{array}$ & + & $+8.158^{* * *}$ & -1.447 \\
\hline Financial (FIN) Sector & + & $-7.476^{*}$ & $+5.915^{\star \star *}$ \\
\hline
\end{tabular}


The results for these three sectors (finance sector, manufacturing sector and wholesale) are plausible due to the sustained efforts in projecting Dubai as the key logistic hub of the middle-east region as envisaged in Dubai Vision 2025. The fourth sector construction and real estate sector unexpectedly had a negative impact on the GDP; one possible reason behind this may be the over-exploitation of the real estate sector in Dubai over the last 1 decade. The real estate sector in Dubai has become saturated and there is overhanging of supply, whereas in other Emirates in UAE it is just catching up. This particular result therefore implies that real estate sector in Dubai needs consolidation without undertaking further investments to ensure long-term sustainability of Dubai GDP.

All other sectors were insignificant implying non-sustainability of these sectors in the long-term. Even though Dubai is considered a re-export market, the impact of re-export sector was negative and insignificant over the study period. One possible reason might be the saturation of the re-export market similar to real estate and construction sectors.

- In the rest of UAE, the transportation sector is making in road as diversification from non-oil sector. This sector in rest of UAE has just picked up pace after taking clue from Dubai and thus had a major impact on the rest of UAE GDP than in Dubai GDP. Whether this sector is sustainable in rest of UAE economy is a question worth review after 5-6 years. The mining sector is the second biggest sector. It influences the rest of UAE GDP significantly and positively. The magnitude of contribution of the mining sector to the GDP is far more intense in rest of UAE than Dubai, which indicates sustainability of mining sector in rest of UAE in the future. The third sector is wholesale and retail sector, which had a positive impact, but in comparison with Dubai, the magnitude was higher and less significant indicating that this may not be sustainable for long-term. This may be due to the reason that rest of UAE has their own regulatory powers for setting up manufacturing units. The government laws, emirates' laws and free zone laws can be complex and confounding. The fourth sector is re-export sector, which positively contributed to the growth of rest of UAE GDP. The Finance sector negatively influenced the rest of UAE GDP although the impact was less significant; implying that financial investments in this sector have not reaped adequate returns since the investments in this sector are in the initial phases and the benefits will start flowing to rest of UAE economy in the long-term.

\subsection{Discussion of NN Results}

Table 5.2 shows the importance of factors in NN model for explaining the economic behavior in Rest of UAE and Dubai. Some of these variables were insignificant in SURE model. Highlighted rows relate to equation 1 (rest of UAE) NN forecasts that, Re-exports, Mining, Manufacturing, Transport, Construction \& Real Estate, Whole sale sector and Finance sector contribute (in decreasing order) for the growth and sustainability in rest of UAE. On the other hand, Transport, Finance, Wholesale, Manufacturing, Re-export, Mining and Construction and Real Estate sector contribute in decreasing order for the growth and sustainability of Dubai GDP.

Table 4.7 Independent Variable Importance

\begin{tabular}{llccc}
\hline \multicolumn{1}{c}{ Variable } & Code & Importance & $\begin{array}{r}\text { Normalized } \\
\text { Importance }\end{array}$ & Rank Order \\
\hline Re-Export & X1 & 0.070 & $86.5 \%$ & 1 \\
Mining & X2 & 0.068 & $83.8 \%$ & 2 \\
Wholesale & X3 & 0.064 & $79.0 \%$ & 6 \\
CREST & X4 & 0.066 & $81.5 \%$ & 5 \\
Manufacturing & X5 & 0.066 & $81.8 \%$ & 3 \\
Transport & X6 & 0.066 & $81.7 \%$ & 4 \\
Finance & X7 & 0.058 & $72.0 \%$ & 7 \\
Re-Export & X1D & 0.065 & $80.1 \%$ & 5 \\
Mining & X2D & 0.065 & $79.9 \%$ & 6 \\
Wholesale & X3D & 0.067 & $83.3 \%$ & 7 \\
CREST & X4D & 0.064 & $79.1 \%$ & 4 \\
Manufacturing & X5D & 0.065 & $80.7 \%$ & 1 \\
Transport & X6D & 0.068 & $83.8 \%$ & 2 \\
Finance & X7D & 0.068 & $83.5 \%$ & \\
\hline
\end{tabular}




\subsection{Policy Implications}

The study conclusions point to prudent management of Governments' investments in both economies towards non-hydrocarbon GDPs. Raising more nonhydrocarbon revenues through new value added tax measures being implemented from 2017-18 could be the starting point for such prudent management of resources. The positive sizable impact of the finance sector in Dubai and negative sizable impact in the rest of the UAE provide many opportunities for designing diversification programs for sustained economic development of the entire UAE economy. The proposed structural reforms in the UAE in 2025 Vision document, could aim at further diversifying the economy and accelerating private sector-led job creation for nationals. These could include further opening up foreign direct investment, improving selected areas of business environment, transitioning toward a knowledge-based economy with focus and support to fundamental research, easing access to finance for startups and SMEs, and creating the right incentives for innovation, entrepreneurship and job creation.

\subsection{Study Limitations}

The study has few limitations. First, the sample size of the data was small covering the years 2001-2015 (15 years), which constrained the choice of applying VAR as analytical tool for studying co-integration between Dubai and rest of UAE economies. The second limitation was the lack of sectoral data in four emirates in UAE, which could have broadened the scope of the study. To that extent, the model results may not be generalizable to other economies in the Middle-East region. With more data, NN analysis could have given better insights in to the long-term sustainability and growth of both economies. Future studies can address these limitations.

\section{REFERENCES}

Ajmair, M. (2014). Impact of industrial sector on GDP (Pakistan Case). European Journal of Contemporary Economics and Management, Edition Vol.1 No.1.

Aqeel, A., \& Sabihuddin Butt, M. (2001). The relationship between energy consumption and economic growth in Pakistan. Asia-Pacific Development Journal, Vol. 8, No. 2.

Awokuse, T. (2007). Causality between exports, imports, and economic growth: Evidence from transition economies. Economics Letters, 94(3), 389-395.

Beresteanu, Ariel (2004). Nonparametric Estimation of Regression Functions under Restrictions on Partial Derivatives. Working Paper, Department of Economics, Duke University. https://ideas.repec.org/p/duk/dukeec/04-06.html

Calderón, C. and Liu, L. (2003). The direction of causality between financial development and economic growth. Journal of Development Economics, 72: 321-334.

Cevik, S. (2014). Without Oil, How Do Gulf Countries Move? Non-hydrocarbon Business Cycles. Journal of Economic Integration, 29: 244-266.

Chui, L. and Chau, K. (2005). An Empirical Study of the Relationship between Economic Growth, Real Estate Prices and Real Estate Investments in Hong Kong, Surveyingand Built Environment.

Dhaheri, Jamal. (2016). UAE Economy Will Benefit From A Focus On Industry In Schools. The National, https://www.thenational.ae/business/uae-economy-will-benefit-from-a-focus-on-industry-in-schools-1.190059

Drewer, S (1997). Construction and development: Further reflections on the work of Duccio Turin. Proceedings of the First International Conference on Construction Industry Development, Singapore 9-11 December.

Fernandes, Cedwyn and Ajit Karnik (2009). Assessing UAE's Oil Dependence: An Optimal Control Approach. Education, Business and Society: Contemporary Middle Eastern Issues Vol.2, No.2, pp138-152.

Gao, Y., Zhang, Y., Li, H., Peng, T., \& Hao, S. (2016). Study on the Relationship between Comprehensive Transportation Freight Index and GDP in China. Procedia Engineering, 137, 571-580. http://dx.doi.org/10.1016/i.proeng.2016.01.294

Guo, H. and. Kliesen, K (2005). Oil Price Volatility and U.S. Macroeconomic Activity. Federal Reserve Bank of St. Luis, Review, Vol. 87, No.6, pp. 669-683.

International Monetary Fund (2015). IMF Country Report N0.15, August 2015.

International Monetary Fund (2016). United Arab Emirates: 2016 Article IV Consultation-Press Release. Staff Report and Statement by The Executive Director for The United Arab Emirates, IMF Staff Country Reports 16.251.

Hong, L. (2014). The Dynamic Relationship between Real Estate Investment and Economic Growth: Evidence from Prefecture City Panel Data in China. IERI Procedia, 7:2-7.

Husain, A., Tazhibayeva, K. and Ter-Martirosyan, A. (2008). Fiscal Policy and Economic Cycles in Oil-Exporting Countries. IMF Working Paper, WP/08/253, International Monetary Fund (Washington). 
Karnik, A. and Fernandes, C.J. (2007). Natural resource dependence: a macro-econometric model for the United Arab Emirates. Applied Economics, Vol.41, No. 9, pp 1157-74.

Mahonye, N. and Mandishara, L. (2015). Mechanism Between Mining Sector and Economic Growth in Zimbabwe, Is It a Resource Curse? Economic Research Southern Africa (ERSA).

Rettab, B. (2016). 18 $8^{\text {th }}$ Annual International Conference of the Global Business and Technology Association (GBATA) on October 19, University of Dubai, UAE.

Rustichini, Aldo \& Dickhaut, John \& Ghirardato, Paolo \& Smith, Kip \& Pardo, Jose V. (2005). A brain imaging study of the choice procedure. Games and Economic Behavior, Elsevier, vol. 52(2), pages 257-282, August.

Shahbaz, M., Khan, S., and Tahir, M. (2013). The dynamic links between energy consumption, economic growth, financial development and trade in China: Fresh evidence from multivariate framework analysis. Energy Economics, 40:8-21.

Shakouri, B. and Yazdi, S. (2012). Granger Causality Relationship between Mining Exports and GDP Growth in Iran. Australian Journal of Basic and Applied Sciences, 6(12):429-435.

Sherif, S. (2013). Macroeconomic Policy, Localization, and Reducing Unemployment: The Human Resource Issues for the UAE Competitiveness Review. International Business Journal, 23(2), 158-174.

United Arab Emirates(UAE) (2012). UAE Annual Economic Report - 2012. UAE Ministry of Economy, Issue: 20 , p. 23. https://www.economena.com/data-catalog/view6466/

Uğur, A. (2008). Import and Economic Growth in Turkey: Evidence from Multivariate VAR Analysis. Journal of Economics and Business, Vol. XI - 2008, No 1 \& No 2.

Wang, J. (2009). An Empirical Study of the Relationship between Transportation and Economic Growth in Xinjiang Province. International Business Research, 2(2). http://dx.doi.org/10.5539/ibr.v2n2p110.

\footnotetext{
i The appeal of the neural network approach lies in its assumption of bounded rationality: when we forecast in volatile emerging markets, we are approximating the expectations of others. Market participants are thus engaged in a learning process, continually adapting prior subjective beliefs from past mistakes. What makes the neural network approach so appealing in this respect is that it permits threshold responses by economic decision makers to changes in policy or exogenous variablesi. In the neural network model, one is not making any specific hypothesis about the values of the coefficients to be estimated in the model, nor, for that matter, any hypothesis about the functional form relating the observed repressor " $x$ " to an observed output " $y$ ". Most of the time, we cannot even interpret the meaning of the coefficients estimated in the neural network, at least in the same way we can interpret estimated coefficients in ordinary econometric models, with a well-defined functional form. In that sense, the neural network differs from the usual econometrics, where considerable effort is made to obtain accurate and consistent, if not unbiased, estimates of particular parameters or coefficients. Similarly, when nonlinear models are used, too often economists make use of numerical algorithms based on assumptions of continuous or "smooth" data. All too often, these methods break down, or one must make use of repeated estimation, to make sure that the estimates do not represent one of several possible sets of local optimum positions. Various sectors of emerging markets, in particular, with a great deal of innovation and change, represent a fertile ground for the use of neural network for two reasons, which are interrelated. One is that the data are often very noisy, due either to the thinness of the markets or to the speed with which news becomes dispersed, so that there are obvious asymmetries and nonlinearities that cannot be assumed away. Second, in many instances, the players in these markets are themselves in a process of learning, by trial and error, about policy news or about legal and other changes taking place in the organization of their markets. The parameter estimates of a neural network, by which market participants forecast and make decisions, are themselves the outcome of a learning and search process.
} 